\title{
TREATMENT ACTIVITIES IN MALES WITH GONADODYSTROPHY USING DRUGS BASED ON NANOBIOMATERIALS
}

\author{
Naumenko S. V., Koshevoy V. I. \\ Kharkiv State Zooveterinary Academy, Kharkiv, \\ Ukraine, e-mail: vsevolod_koshevoy@yahoo.com
}

\begin{abstract}
Summary. The article presents data on the development of innovative methods of treating males with gonadodystrophy using drugs based of nanobiomaterials. The complex drug 'Karafand+OV,Zn' contains carotenoids, phytoandrogens, and nanomaterials - nanoparticles of gadolinium orthovanadate activated by europium and zinc carbonate, it restores and activates the function of the testes, which generally normalizes the reproductive function of males. The developed methods are simple to implement and can be introduced into the practice of veterinary medicine as correctors of vitamin-hormonal metabolism, with a predominant antioxidant effect
\end{abstract}

Keywords: andrology, males, gonadodystrophy, therapy, nanomaterials, complex preparation 'Karafand+OV,Zn'

Introduction. Alimentary deficient and toxic factors are a common cause of the development of various pathological processes, including processes in the reproductive system of males. Such processes cause damage to the tissues of regulatory organs and organs performing the reproductive function, mainly of a dystrophic nature (Medvedev and Turchanov, 1999; Naumenko, 2009; Koshevoy and Naumenko, 2015).

The combination of such processes with a marked decrease in the reproductive function of males, without clinical manifestations, is called gonadodystrophy. Depending on the etiological factor, there are distinguished an alimentary type of gonadodystrophy (in case of alimentary deficient states in the body - a deficiency of carotene, vitamin A, Zinc) and toxic (with nitrate-nitrite toxicosis, mycotoxicosis) (Koshevoy et al., 2015; Naumenko and Koshevoy, 2017).

The development of methods for the treatment and prevention of gonadodystrophy in males is an urgent problem that requires constant research; the creation of drugs based on nanobiomaterials is its main component (Koshevoy et al., 2016).

The purpose of the study was to develop innovative methods for treating males with gonadodystrophy using drugs based on nanobiomaterials and to determine the therapeutic efficacy and pharmacological activity of the complex drug 'Karafand + OV, Zn'.

Materials and methods. This work was performed in the laboratories of the Department of Veterinary Reproductology of the Kharkiv State Zooveterinary Academy and in the Laboratory of Nanostructured Organic Materials of the Institute for Scintillation Materials of the National Academy of Sciences of Ukraine (Kharkiv, Ukraine).

The studies were carried out on bulls $(\mathrm{n}=8)$ and boars $(\mathrm{n}=12)$ with alimentary type gonadodystrophy, which belonged to the Training and Production Center for Plant Breeding and Livestock of the Kharkiv State Zooveterinary
Academy, the Institute of Animal Breeding of the National Academy of Agrarian Sciences of Ukraine (Kharkiv, Ukraine), and the farms of Kharkiv, Dnipropetrovsk and Zaporizhzhya regions of different forms of ownership.

For the treatment of males with gonadodystrophy, the 'Karafand+OV,Zn' complex drug was used, which contained carotenoids, phytoandrogens, and nanomaterials - gadolinium orthovanadate activated by europium and zinc carbonate, in recommended doses (Koshevoy et al., 2017a).

For diagnosis, we used the clinical remotelycontactless and non-invasive method developed by us (Koshevoy et al., 2017b); biochemical and hormonal research methods were used to determine therapeutic efficacy. Blood was taken for studies at the beginning of the experiment (control) and on the $20^{\text {th }}$ day after giving the drug.

Biochemical blood test was performed in the Central Research Laboratory of the National University of Pharmacy (Kharkiv, Ukraine). The amount of zinc was determined by atomic absorption spectrophotometry. Chemiluminescent analysis was performed in Laboratory of Nanostructured Organic Materials of the Institute for Scintillation Materials of the National Academy of Sciences of Ukraine. The concentration of testosterone was determined in the V. Danilevsky Institute for Endocrine Pathology Problems of the National Academy of Medical Sciences of Ukraine (Kharkiv, Ukraine) using the ELISA test system ('Granum Laboratory' Ltd., Ukraine).

Results. We have developed an innovative method of treating males with gonadodystrophy using the complex drug 'Karafand+OV,Zn'. This drug was administered, according to the recommendations, once a day, orally, the dosage was adjusted by the data on the number of deficient factors in feed and water.

As can be seen from the data in the Table the drug showed high therapeutic efficacy. 
Table - Biochemical blood parameters of males under the influence of the complex drug 'Kararafand+OV,Zn' $(\mathrm{M} \pm \mathrm{m})$

\begin{tabular}{|c|c|c|c|c|}
\hline \multirow[b]{2}{*}{ Indicators } & \multicolumn{2}{|c|}{ Bulls $(n=8)$} & \multicolumn{2}{|c|}{ Boars $(n=12)$} \\
\hline & $\begin{array}{c}\text { before } \\
\text { administration }\end{array}$ & $\begin{array}{c}\text { after } \\
\text { administration }\end{array}$ & $\begin{array}{c}\text { before } \\
\text { administration }\end{array}$ & $\begin{array}{c}\text { after } \\
\text { administration }\end{array}$ \\
\hline Vitamin $A, \mu \mathrm{mol} / \mathrm{l}$ & $0.8 \pm 0.06$ & $1.4 \pm 0.08^{\star}$ & $0.19 \pm 0.03$ & $0.62 \pm 0.05^{\star}$ \\
\hline Carotene, $\mu \mathrm{mol} / \mathrm{l}$ & $2.7 \pm 0.02$ & $7.9 \pm 0.05$ & not determined & not determined \\
\hline Zinc, $\mu \mathrm{mol} / \mathrm{l}$ & $12.4 \pm 0.21$ & $20.2 \pm 0.14$ & $8.4 \pm 0.02$ & $11.6 \pm 0.23^{*}$ \\
\hline Total protein, $\mathrm{g} / \mathrm{l}$ & $72.5 \pm 0.4$ & $82.2 \pm 0.3^{\star}$ & $68 \pm 2.2$ & $81 \pm 1.4^{*}$ \\
\hline Inorganic calcium, $\mu \mathrm{mol} / \mathrm{l}$ & $2.79 \pm 0.01$ & $2.96 \pm 0.01^{\star}$ & $2.5 \pm 0.13$ & $3.5 \pm 0.16^{*}$ \\
\hline Inorganic phosphorus, $\mu \mathrm{mol} / \mathrm{l}$ & $1.5 \pm 0.01$ & $2.2 \pm 0.01$ & $1.32 \pm 0.006$ & $1.98 \pm 0.06^{*}$ \\
\hline $\begin{array}{l}\text { Content in red blood cells: } \\
\text { Malonic dialdehyde, } \mu \mathrm{mol} / 1\end{array}$ & $45.7 \pm 0.04$ & $24.6 \pm 0.05$ & $57.3 \pm 0.03$ & $35.3 \pm 0.01$ \\
\hline $\begin{array}{l}\text { Catalase, } \\
\mu \mathrm{mol} / \mathrm{H}_{2} \mathrm{O}_{2} / \mathrm{l}-\mathrm{min}\end{array}$ & $15.9 \pm 0.06$ & $26.7 \pm 0.08$ & $14.8 \pm 0.02$ & $37.8 \pm 0.4$ \\
\hline Reduced glutathione, $\mu \mathrm{mol} / \mathrm{l}$ & $3.24 \pm 0.04$ & $3.87 \pm 0.07^{\star}$ & $3.21 \pm 0.88$ & $3.81 \pm 0.07$ \\
\hline $\begin{array}{l}\text { Serum contents: } \\
\text { Malonic dialdehyde, } \mu \mathrm{mol} / 1\end{array}$ & $0.82 \pm 0.04$ & $0.28 \pm 0.05^{*}$ & $0.83 \pm 0.03$ & $0.41 \pm 0.01^{*}$ \\
\hline $\begin{array}{l}\text { Catalase, } \\
\mu \mathrm{mol} / \mathrm{H}_{2} \mathrm{O}_{2} / \mathrm{l}-\mathrm{min} \\
\end{array}$ & $20.3 \pm 0.07$ & $43.2 \pm 0.04$ & $23.7 \pm 0.72$ & $41.4 \pm 0.52^{\star}$ \\
\hline $\begin{array}{l}\text { Superoxide dismutase, } \\
\text { st. un./mgHb }\end{array}$ & $5.3 \pm 0.09$ & $9.3 \pm 0.07$ & $5.7 \pm 0.41$ & $10.7 \pm 0.02^{*}$ \\
\hline Prooxidant-antioxidant ratio & $3: 1$ & $1: 1$ & $3: 1$ & $1: 1$ \\
\hline $\begin{array}{l}\text { Chemiluminescence: } \\
\text { Light sum, un. }\end{array}$ & $8.4 \pm 0.04$ & $3.5 \pm 0.05$ & $8.1 \pm 0.12$ & $4.2 \pm 0.1^{\star}$ \\
\hline Red blood cells, $\times 10^{12} / 1$ & $5.9 \pm 0.1$ & $7.2 \pm 0.3^{\star}$ & $5.8 \pm 0.7$ & $6.8 \pm 0.6$ \\
\hline $\begin{array}{l}\text { Hemoglobin } \\
\text { concentration, g/l }\end{array}$ & $98 \pm 0.03$ & $114 \pm 0.02$ & $86 \pm 0.01$ & $104 \pm 0.02$ \\
\hline $\begin{array}{l}\text { Concentration of 2,3- } \\
\text { diphosphoglycerate, } \mathrm{mmol} / \mathrm{l}\end{array}$ & $0.8 \pm 0.031$ & $1.3 \pm 0.031^{\star}$ & $0.9 \pm 0.045$ & $1.4 \pm 0.049^{\star}$ \\
\hline $\begin{array}{l}\text { Testosterone } \\
\text { concentration }\end{array}$ & $\begin{array}{c}7.1 \pm 0.12 \\
\mathrm{mmol} / \mathrm{l}\end{array}$ & $\begin{array}{c}16.9 \pm 0.21 \\
\mathrm{mmol} / \mathrm{l}\end{array}$ & $\begin{array}{c}4.9 \pm 0.35 \\
\mathrm{nmol} / 1\end{array}$ & $\begin{array}{c}17.7 \pm 0.02 \\
\mathrm{nmol} / 1\end{array}$ \\
\hline
\end{tabular}

Note: ${ }^{*}-\mathrm{P}<0.001$ in comparison with the indicators before drug administration.

The drug showed the greatest efficiency in terms of the content of environmentally deficient factors: carotene concentration in bulls increased by 1.92 times; vitamin A content increased in bulls by 0.75 times, in boars - by 2.26 times; zinc content increased in bulls by $62.9 \%$, in boars - by $38.1 \%$. Normalization of protein-mineral metabolism was noted.

Positive dynamics was found in the prooxidantantioxidant system and oxygen metabolism: the content of malonic dialdehyde in blood serum and erythrocytes decreased in bulls - by 65 and $46 \%$, in boars - by 51 and $38.4 \%$, respectively; catalase activity increased significantly and SOD in the blood serum of bulls by 112 and $75.5 \%$, boars - by 87.2 and $87.7 \%$, respectively; catalase and reduced glutathione increased in red blood cells of bulls by 62.9 and $19.4 \%$, boars - 155 and $18.7 \%$, respectively.
A significant increase in the concentration of 2,3diphosphoglycerate was noted (in bulls - by $62.5 \%$, in boars - by $55.6 \%$ ).

By increasing the testosterone content in the blood serum of males (in bulls - by 1.4 times, in boars - by 2.6 times), we can conclude about positive changes in hormonal levels.

Conclusions. Innovative methods of treating males with gonadodystrophy using drugs based on nanobiomaterials are effective.

The complex preparation 'Karafand+OV,Zn' restores and activates the function of the testes, which generally normalizes the reproductive function of males.

This drug and its application are simple and can be successfully implemented in the practice of veterinary medicine. 


\section{References}

Koshevoy, V. P. and Naumenko, S. V. (2015) 'Testodystrophy of bulls: methods of treatment and prevention' [Testodystrofiia u buhaiv: metody terapii i profilaktyky], Scientific Messenger of Lviv National University of Veterinary Medicine and Biotechnologies. Series: Veterinary Sciences [Naukovyi visnyk Lvivskoho natsionalnoho universytetu veterynarnoi medytsyny ta biotekhnolohii. Seriia: Veterynarni nauky], 17(1.1), pp. 72-79. Available at: http://nbuv.gov.ua/UJRN/nvlnu_2015_17_1(1) 16. [in Ukrainian].

Koshevoy, V. P., $\quad$ Naumenko, S. V., $\quad$ Koshevoy, V. I., Maliukin, Yu. V., Klochkov, V. K. and Kavok, N. S. (2015) 'Computer monitoring of the indicators of structural and functional conditions of the reproductive system organs in males at deficiency of carotene (vitamin A) and zinc' [Kompiuternyi monitorynh pokaznykiv strukturnofunktsionalnoho stanu orhaniv reproduktyvnoi systemy $\mathrm{u}$ samtsiv pry defitsyti karotynu (vitaminu A) ta Tsynku], Problems of Zooengineering and Veterinary Medicine [Problemy zooinzhenerii ta veterynarnoi medytsyny], 31(2), pp.62-70. Available at: http://nbuv.gov.ua/UJRN/pzvm_2015_31(2)_16. [in Ukrainian].

Koshevoy, V. P., $\quad$ Fedorenko, S. Ya., $\quad$ Naumenko, S. V., Ivanchenko, M. M., Onyshchenko, O. V. and Besedovska, K. S. (2016) Complex Preparations Based on Nano-Biomaterials and Their Use in Veterinary Reproductology: Methodological Recommendations [Kompleksni preparaty, stvoreni na osnovi nano-biomaterialiv, ta yikh vykorystannia $u$ veterynarnii reproduktolohii: metodychni rekomendatsii]. Dnipropetrovsk: Porohy.

Koshevoy, V. P., Naumenko, S. V., Koshevoy, V. I. and Skliarov, P. M. (2017a) Distance Non-Contact and Noninvasive Diagnostics of Pathological Processes in Male Gonads: Methodological Recommendations [Dystantsiino-bezkontaktna ta neinvaziina diahnostyka patolohichnykh protsesiv u honadakh samtsiv: metodychni rekomendatsii]. Kharkiv: Kharkiv State Zooveterinary Academy. [in Ukrainian].

Koshevoy, V. P., $\quad$ Naumenko, S. V., $\quad$ Koshevoy, V. I., Skliarov, P. M., Maliukin, Yu. V., Klochkov, V. K. and Bespalova, I. I. (2017b) Complex Drug 'Karafand $+O V$,Zn' and Its Use for Gonadodystrophy in Males: Methodological Recommendations [Kompleksnyi preparat 'Karafand $+\mathrm{OV}, \mathrm{Zn}$ ' ta yoho vykorystannia za honadodystrofii u samtsiv: metodychni rekomendatsii]. Kharkiv: Kharkiv State Zooveterinary Academy. [in Ukrainian].

Medvedev, G. F. and Turchanov, S. O. (1999) 'Dependence of the bulls' fertility on the morphological development of their gonads' [Zavisimost' plodovitosti bykov-proizvoditeley ot morfologicheskogo razvitiya ikh polovykh zhelez], Proceedings of the Academy of Sciences of Republic of Belarus. Agrarian Series [Izvestiya Natsional'noy akademii nauk Belarusi. Seriya agrarnykh nauk], 2, pp. 68-72. Available at: http://vesti.belal.by/ vesti/pdf/19990217.pdf. [in Russian].

Naumenko, S. V. (2009) 'Retinol-deficient hypopotency in males and development of method of prophylaxis' [Retynoldefitsytna hipopotentsiia u samtsiv ta rozrobka sposobu profilaktyky], Problems of Zooengineering and Veterinary Medicine [Problemy zooinzhenerii ta veterynarnoi medytsyny], 19(2.2), pp. 279-285. Available at: http://library.hdzva.edu.ua/ resurs/zbirn/19vet20092.doc. [in Ukrainian].

Naumenko, S. V. and Koshevoy, V. I. (2017) 'Biochemical changes in organism of males at gonadodystrophy at terms of chronic nitrate-nitrite toxicosis' [Biokhimichni zminy $\mathrm{v}$ orhanizmi samtsiv pry honadodystrofii za umov khronichnoho nitratno-nitrytnoho toksykozu], Problems of Zooengineering and Veterinary Medicine [Problemy zooinzhenerii ta veterynarnoi medytsyny], 34(2), pp. 183-186. Available at: http://nbuv.gov.ua/ UJRN/pzvm_2017_34(2)_42. [in Ukrainian]. 